\title{
Rhaponticum carthamoides regeneration through direct and indirect organogenesis, molecular profiles and secondary metabolite production
}

\author{
Ewa Skała $^{1} \cdot$ Renata Grąbkowska $^{1} \cdot$ Przemysław Sitarek $^{1} \cdot$ Lukasz Kuźma $^{1}$ • \\ Andrzej Błauż ${ }^{2} \cdot$ Halina Wysokińska ${ }^{1}$
}

Received: 20 January 2015/ Accepted: 28 June 2015/Published online: 7 July 2015

(c) The Author(s) 2015. This article is published with open access at Springerlink.com

\begin{abstract}
The organogenic competence of different explants of Rhaponticum carthamoides was investigated on MS agar medium supplemented with BA, IBA or NAA at concentrations of 0.2 and $0.5 \mathrm{mg} \mathrm{L}^{-1}$. Adventitious shoot formation was obtained through direct organogenesis using leaves of in vitro cultures as explants and through indirect organogenesis when seedling explants (hypocotyl, cotyledon and root) were used for regenerative callus initiation. The shoots were rooted on half-strength MS medium ( $1 / 2 \mathrm{MS})$ without auxin or containing IBA $\left(0.2-2.0 \mathrm{mg} \mathrm{L}^{-1}\right)$. The plantlets regenerated through direct and indirect organogenesis were transferred into pots and grown in the greenhouse for 3 months. Significant differences in morphology, accumulation of chlorogenic acid and 20-hydroxyecdysone (20-HE) as well as in genetic profile were observed between these plants. UHPLC analysis showed that the highest level of chlorogenic acid (12 $\left.\mathrm{mg} \mathrm{g}^{-1} \mathrm{DW}\right)$ was found in leaves of plants developed directly from explants, whereas leaves of plants developed via callus tissue accumulated the highest amount of 20-HE (7.4 $\left.\mathrm{mg} \mathrm{g}^{-1} \mathrm{DW}\right)$. Its level exceeded that detected in leaves of 3-month-old plants obtained from seeds ( $\left.2.4 \mathrm{mg} \mathrm{g}^{-1} \mathrm{DW}\right)$. Genetic variations of $R$. carthamoides regenerated plants were evaluated by flow cytometry and RAPD and ISSR methods. Flow cytometry confirmed similar ploidy level in the mother plant and plants regenerated through direct and indirect organogenesis. Genetic similarity
\end{abstract}

Ewa Skała

ewa.skala@umed.lodz.pl

1 Department of Biology and Pharmaceutical Botany, Medical University of Łódź, Muszyńskiego 1, 90-151 Łódź, Poland

2 Cytometry Laboratory, Department of Molecular Biophysics, University of Lódź, ul. Pomorska 141/143, 90-236 Łódź, Poland values calculated on the basis of RAPD and ISSR data among regenerated in vitro plants to the mother plant were ranged from 0.765 to 0.941 and 0.647 to 0.947 , respectively.

Keywords Rhaponticum carthamoides - Organogenesis . RAPD and ISSR - Flow cytometry · Chlorogenic acid . 20-hydroxyecdysone

\begin{tabular}{|c|c|}
\hline \multicolumn{2}{|c|}{ Abbreviations } \\
\hline 20-HE & 20-Hydroxyecdysone \\
\hline 2,4-D & 2,4-Dichlorophenoxyacetic acid \\
\hline BA & 6-Benzyladenine \\
\hline DSO-plants & $\begin{array}{l}\text { Plants regenerated through direct } \\
\text { organogenesis }\end{array}$ \\
\hline IAA & Indole-3-acetic acid \\
\hline IBA & Indole-3-butyric acid \\
\hline IDSO-plants & $\begin{array}{l}\text { Plants regenerated through indirect } \\
\text { organogenesis }\end{array}$ \\
\hline ISSR & Inter-simple sequence repeats \\
\hline MS & Murashige and Skoog medium (1962) \\
\hline NAA & $\alpha$-Naphtaleneacetic acid \\
\hline RAPD & Random amplified polymorphic DNA \\
\hline SE & Standard error \\
\hline SP & Seed-derived plants \\
\hline UHPLC & $\begin{array}{l}\text { Ultra high performance liquid } \\
\text { chromatography }\end{array}$ \\
\hline
\end{tabular}

\section{Introduction}

Rhaponticum carthamoides (Willd.) Iljin (known as "maral root" or Russian leuzea) is an endemic, perennial, herbaceous plant belonging to the family Asteraceae. The plants originate from the mountains of South Siberia, Central Asia 
and China (Timofeev et al. 2006; Kokoska and Janovska 2009). The roots and rhizomes of $R$. carthamoides have been used for a long time in Siberian folk medicine in the treatment of overstrain and weakness after illness. They also have adaptogenic, antioxidant, immunomodulatory, anticancerogenic and antimicrobial properties (Kokoska et al. 2002; Biskup and Lojkowska 2009; Kokoska and Janovska 2009). The raw material (roots and rhizomes) of $R$. carthamoides is used to eliminate physical and mental weariness, and to promote muscle growth and sexual function (Kokoska and Janovska 2009). The major chemical constituents in this plant are ecdysteroids, flavonoids, phenolic acids, triterpenoid glycosides, polyacetylenes and sesquiterpene lactones (Kokoska and Janovska 2009). Harvesting the roots and underground parts requires the plant to be cut down, which has led to the depletion of $R$. carthamoides from its natural habitat. The development of biotechnological methods such as micropropagation is one solution which may overcome this problem. There are few reports on the in vitro propagation of $R$. carthamoides. Duškova and Dušek (1995) regenerated the plant species from cotyledon-derived callus, while Zand et al. (2014) obtained shoots of $R$. carthamoides from both leaf-derived callus and directly from root explants. However, the genetic stability of in vitro regenerated plants has not been studied so far.

Clonal fidelity is an imperative among in vitro regenerated plants. A major problem associated with in vitro cultures might be the occurrence of somaclonal variation, mainly in callus-derived plants. Of several molecular markers used for assessment of genetic fidelity of in vitro regenerated plants, random amplified polymorphic DNA (RAPD) and inter-simple sequence repeats (ISSR) marker analyses are simple, quick and cost-effective methods. The use of techniques to successfully assess the genetic fidelity of several plant species like Saussurea involucrate (Yuan et al. 2009), Hydrangea macrophylla (Liu et al. 2011), Garcinia sp. (Mohat et al. 2012) or Withania somnifera (Nayak et al. 2013) has been recently reported. Flow cytometry for genome size estimation can be used to complement molecular marker analyses (Slazak et al. 2015).

The present study describes the regeneration of $R$. carhamoides plants through direct (from leaves of in vitro culture) and indirect organogenesis (from hypocotyl, cotyledon and root of 3-week-old seedling). The assessment of genetic variation of the regenerated plants by RAPD and ISSR markers, and flow cytometry was performed. To evaluate whether or not the regeneration pathway altered the biosynthesis of secondary metabolites in $R$. carthamoides, the contents of chlorogenic acid and 20-hydroxyecdysone (20-HE) in leaves and roots of $R$. carthamoides plants derived through direct and indirect organogenesis were determined using UHPLC method, the results being compared to the respective parts of seedderived plants. Chlorogenic acid and 20-hydroxyecdysone are known to be the principle compounds responsible for therapeutic effects of extracts of $R$. carthamoides. Chlorogenic acid is a free radical and metal scavenger; it may interfere with glucose absorption and has been shown to modulate gene expression of antioxidant enzymes (Clifford 1999; Olthof et al. 2001). 20-HE is known to have antioxidant and anti-inflammatory properties (Zhou et al. 2012), and to exert a stimulatory effect on protein synthesis and increase metabolic activity (Sláma and Lafont 1995).

\section{Materials and methods}

\section{Plant material}

Rhaponticum carthamoides seeds were obtained from the Medicinal Plant Garden of the Department of Pharmacognosy, Medical University of Łódź (Poland). The botanical identity of plants was confirmed by E. Skała according to Flora of China (www.eFloras.org). The seeds were sterilized with $2 \%$ sodium hypochlorite solution for $10 \mathrm{~min}$ and then rinsed three times (15 min, each) in sterile distilled water. For germination, seeds were placed on Murashige and Skoog (MS; 1962) agar (0.7\%) medium supplemented with $3 \%$ sucrose, gibberellic acid $\left(0.1 \mathrm{mg} \mathrm{L}^{-1}\right)$ and kinetin $\left(0.02 \mathrm{mg} \mathrm{L}^{-1}\right)$.

\section{Indirect shoot regeneration}

The cotyledons, hypocotyl and roots of the 3-week-old single seedling were used as explants for callus induction. The cotyledons were divided into quarters, the hypocotyl and roots were cut into sections of $5 \mathrm{~mm}$ in length. The explants were placed horizontally on MS agar $(0.7 \%)$ medium supplemented with auxin: 2,4-D, NAA or IBA in combination with cytokinin, BA. The growth regulators were used at concentrations of 0.2 or $0.5 \mathrm{mg} \mathrm{L}^{-1}$. The ratio between cytokinin and auxin in the media was $2.5: 1$ or $1: 2.5$. Organogenic calluses generated from different seedling explants were subcultured every 5 weeks on fresh MS medium of the same composition. After 5 weeks, the percentage of calluses inducing buds/shoots (organogenesis frequency) and the average number of adventitious buds/shoots per callus were determined for three successive passages (3-5). 5-15 calluses were used for each explant type and medium combination. The results are presented in Table 1 .

\section{Direct shoot organogenesis}

The shoot tip (about $5 \mathrm{~mm}$ long) excised from the same 3-week-old seedling of $R$. carthamoides, which was used to 
initiate callus cultures was transferred into MS agar medium containing $0.1 \mathrm{mg} \mathrm{L}^{-1}$ IAA and $0.2 \mathrm{mg} \mathrm{L}^{-1} \mathrm{BA}$. Following the establishment of the shoot culture, the shoots were subcultured regularly at 5-week-intervals on MS medium, as described above. After 5 passages, leaves of the shoots were taken as starting material. The leaves were cut into lamina (about $0.5 \times 0.5 \mathrm{~cm}$; length $\times$ width) and petiole (about $1 \mathrm{~cm}$ in length). The explants were placed horizontally with their abaxial side down on MS agar $(0.7 \%)$ medium supplemented with BA $(0.2$ or $0.5 \mathrm{mg} \mathrm{L}^{-1}$ ) alone or in combination with auxin IBA or NAA $\left(0.2\right.$ or $\left.0.5 \mathrm{mg} \mathrm{L}^{-1}\right)$. The ratio of cytokinin to auxin in the media was $2.5: 1$ or 1:2.5. After 5 weeks, the percentage of explants forming adventitious shoots (organogenesis frequency) and the average number of buds/shoots per explant were recorded (Table 2). The measurements were repeated three times, using 20 of each type explants for each replicate.

\section{Culture conditions}

Incubation was performed in a growth chamber at $26 \pm 2{ }^{\circ} \mathrm{C}$ and $16 \mathrm{~h}$ photoperiod (light intensity of $40 \mu \mathrm{mol} \mathrm{m} \mathrm{m}^{-2} \mathrm{~s}^{-1}$ provided by fluorescent tubes).

\section{Shoot rooting and plantlet acclimatization}

Excised shoots regenerated from root-derived callus and leaf explants were transferred into MS agar $(0.7 \%)$ medium with half-strength concentration of macro- and micronutrients $(1 / 2 \mathrm{MS})$ without growth regulators or supplemented with IBA at concentrations of $0.2,0.5,1.0,1.5$ or $2.0 \mathrm{mg} \mathrm{L}^{-1}$. The cultures were incubated under the same conditions as above. After 5 weeks, the percentage of shoots forming roots, the average number roots per rooted shoot and the average length of roots $(\mathrm{cm})$ were recorded. The results presented in Fig. 1, are means of three replications: each replicate comprising 15 shoots. The rooted plantlets were washed in tap water to remove agar from the roots and transplanted into $10-\mathrm{cm}$-diameter-pots containing a sterilized mixture of soil, sand, peat and perlite (4:3:3:3 v/v/v/v). To maintain high humidity, the potted plantlets were covered with glass, which were gradually opened after 3 days and completely removed after 2 weeks. The potted plantlets were kept in the greenhouse at $26 \pm 2{ }^{\circ} \mathrm{C}$ and natural light. The percentage survival rate of the plants and their morphology were recorded after 3 months. The following characteristics were measured and are presented in Table 3: the mean plant length

Table 1 Indirect shoot organogenesis of $R$. carthamoides from callus culture initiated from different seedling explants. Calluses were cultured on MS agar medium supplemented with different plant growth regulators for 5 weeks

\begin{tabular}{|c|c|c|c|}
\hline Growth regulators $\left(\mathrm{mg} \mathrm{L}^{-1}\right)$ & Type of explants & Organogenesis frequency $(\%)$ & $\begin{array}{l}\text { Mean number of buds/shoots } \\
\text { per callus } \pm \text { SE }\end{array}$ \\
\hline 2,4-D 0.5 & Root & 0 & $0^{\mathrm{a}}$ \\
\hline \multirow[t]{2}{*}{ BA 0.2} & Hypocotyl & 0 & $0^{\mathrm{a}}$ \\
\hline & Cotyledon & 0 & $0^{\mathrm{a}}$ \\
\hline 2,4-D 0.2 & Root & $0^{*}$ & $0^{\mathrm{a}}$ \\
\hline \multirow[t]{2}{*}{ BA 0.5} & Hypocotyl & 0 & $0^{\mathrm{a}}$ \\
\hline & Cotyledon & 0 & $0^{\mathrm{a}}$ \\
\hline NAA 0.5 & Root & 82.6 & $3.47 \pm 0.41^{\mathrm{de}}$ \\
\hline \multirow[t]{2}{*}{ BA 0.2} & Hypocotyl & 88.9 & $2.25 \pm 0.45^{\mathrm{b}}$ \\
\hline & Cotyledon & 92.3 & $3.83 \pm 0.36^{\mathrm{e}}$ \\
\hline NAA 0.2 & Root & 70.0 & $2.79 \pm 0.26^{\mathrm{bc}}$ \\
\hline \multirow[t]{2}{*}{ BA 0.5} & Hypocotyl & 76.9 & $2.70 \pm 0.52^{\mathrm{bc}}$ \\
\hline & Cotyledon & 80.0 & $3.44 \pm 0.52^{\mathrm{de}}$ \\
\hline IBA 0.5 & Root & 66.7 & $2.25 \pm 0.41^{\mathrm{b}}$ \\
\hline \multirow[t]{2}{*}{ BA 0.2} & Hypocotyl & 60.0 & $2.22 \pm 0.32^{\mathrm{b}}$ \\
\hline & Cotyledon & 69.2 & $3.22 \pm 0.46^{\mathrm{cde}}$ \\
\hline IBA 0.2 & Root & 64.3 & $2.44 \pm 0.41^{b c}$ \\
\hline \multirow[t]{2}{*}{ BA 0.5} & Hypocotyl & 42.9 & $2.33 \pm 0.33^{\mathrm{b}}$ \\
\hline & Cotyledon & 73.3 & $2.91 \pm 0.49^{\mathrm{bcd}}$ \\
\hline
\end{tabular}

The values represent the mean \pm standard error (SE). The experiments were conducted with three replicates. 5-15 calluses were used for each explant type and treatment for each experiment. Values within a column followed by the same letter are not significantly different from each other at a $5 \%$ level according to the Kruskal-Wallis test and multiple comparisons of average ranks

* Callus regenerated the numerous roots (about $1 \mathrm{~cm}$ of length) 
Table 2 Direct shoot organogenesis from leaf explants of $R$. carthamoides

\begin{tabular}{llllll}
\hline \multicolumn{2}{l}{ Growth regulators $\left(\mathrm{mg} \mathrm{L}^{-1}\right)$} & & & & $\begin{array}{l}\text { Mean number of buds/shoots } \\
\text { per explant } \pm \text { SE }\end{array}$ \\
\hline NAA & IBA & BA & Type of explant & Organogenesis frequency $(\%)$ & $3.48 \pm 0.39^{\mathrm{ab}}$ \\
\hline- & - & 0.2 & Lamina & 96.9 & $3.97 \pm 0.30^{\mathrm{cd}}$ \\
- & - & 0.2 & Petiole & 96.8 & $3.24 \pm 0.32^{\mathrm{ab}}$ \\
- & - & 0.5 & Lamina & 90.6 & $3.47 \pm 0.27^{\mathrm{ab}}$ \\
0.2 & - & 0.5 & Petiole & 96.8 & $3.83 \pm 0.34^{\mathrm{bcd}}$ \\
0.2 & - & 0.5 & Lamina & 96.8 & $3.61 \pm 0.21^{\mathrm{abc}}$ \\
0.5 & - & 0.5 & Petiole & 100 & $4.48 \pm 0.38^{\mathrm{d}}$ \\
0.5 & - & 0.2 & Lamina & 100 & $4.38 \pm 0.38^{\mathrm{d}}$ \\
- & - & 0.2 & Petiole & 93.5 & $3.08 \pm 0.31^{\mathrm{a}}$ \\
- & 0.2 & 0.5 & Lamina & 85.7 & $3.33 \pm 0.27^{\mathrm{ab}}$ \\
- & 0.2 & 0.5 & Petiole & 82.8 & $4.25 \pm 0.34^{\mathrm{d}}$ \\
\hline
\end{tabular}

The explants were cultured on MS medium for 5 weeks

The values represent the mean $\pm \mathrm{SE}$ of three independent experiments. Each experiment comprised 20 each type explants. Values within a column followed by the same letter are not significantly different from each other at a $5 \%$ level according to the Kruskal-Wallis test and multiple comparisons of average ranks

(determined as greatest leaf length), the number of leaves/plant, the width and length of leaf lamina, length of leaf petiole, maximum root length and average plant fresh weight. The twenty-five plants regenerated from leaf explants (DSO-plants) and 25 plants regenerated from callus (IDSO-plants) were used in this experiment.

For comparison, plants of $R$. carthamoides derived directly from seeds (SP-plants) were used. They were grown under identical conditions as the in vitro regenerated plants i.e. in the greenhouse for 3 months.

\section{Statistical analysis}

The results presented in Tables 1, 2, 3 and 6 and Fig. 1 were subjected to analysis of variance. Differences in mean values were calculated using the Kruskal-Wallis test, with $p=0.05$ being the level of significance. The significance of the differences between means was assessed using multiple comparisons of average ranks. All statistical analyses were performed by Statistica 10.0PL for Windows (StatSoft Inc., Poland).

\section{Molecular analysis}

\section{Plant materials used for the genetic analysis}

Genomic DNA was isolated from fresh roots of ten randomly-selected 3-month-old plants of $R$. carthamoides regenerated through direct organogenesis from lamina explants (DSO-L-plants), petiole explants (DSO-P-plants), and plants regenerated through indirect organogenesis from root-derived callus (IDSO-plants). Additionally, we included in the analysis genomic DNA isolated from fresh roots of the mother plant (MP; a field grown plant which was the source of seeds used for in vitro culture initiation), roots of ten randomly-selected plants obtained through clonal propagation (CP; plants obtained from axillary buds) and root-callus, which was used for induction of shoot organogenesis (RC-line maintained on MS medium supplemented with $0.5 \mathrm{mg} \mathrm{L}^{-1} \mathrm{NAA}$ and $0.2 \mathrm{mg} \mathrm{L}^{-1} \mathrm{BA}$ for one year). The genomic DNA of MP and CP plants was used as the control.

\section{DNA isolation and PCR amplification}

Genomic DNA was extracted using a NucleoSpin Plant II Kit (Macherey-Nagel, Germany). The plant materials $(200 \mathrm{mg}$ ) were powdered in liquid nitrogen and stored at $-80{ }^{\circ} \mathrm{C}$ until extraction. The quantity and quality of DNA samples were estimated by comparing band intensities on $1.5 \%$ agarose gel. Three replicate DNA extractions from the tissue plant were used to assess the consistency of the band profiles. RAPD and ISSR amplifications were repeated at last three times and only the reproducible PCR products were scored.

\section{RAPD analysis}

RAPD amplification was carried out in a $25 \mu \mathrm{L}$ reaction volume containing $2.5 \mu \mathrm{g}$ DNA $(2 \mu \mathrm{L}), 2.5 \mu \mathrm{L}$ of $10 \times$ PCR buffer (100 mM Tris-HCl, pH 8.3, $500 \mathrm{mM} \mathrm{KCl,}$ $11 \mathrm{mM} \mathrm{MgCl} 2,0.1 \%$ gelatin), $1.5 \mu \mathrm{L} \mathrm{MgCl}_{2}, 0.75 \mu \mathrm{L}$ of 

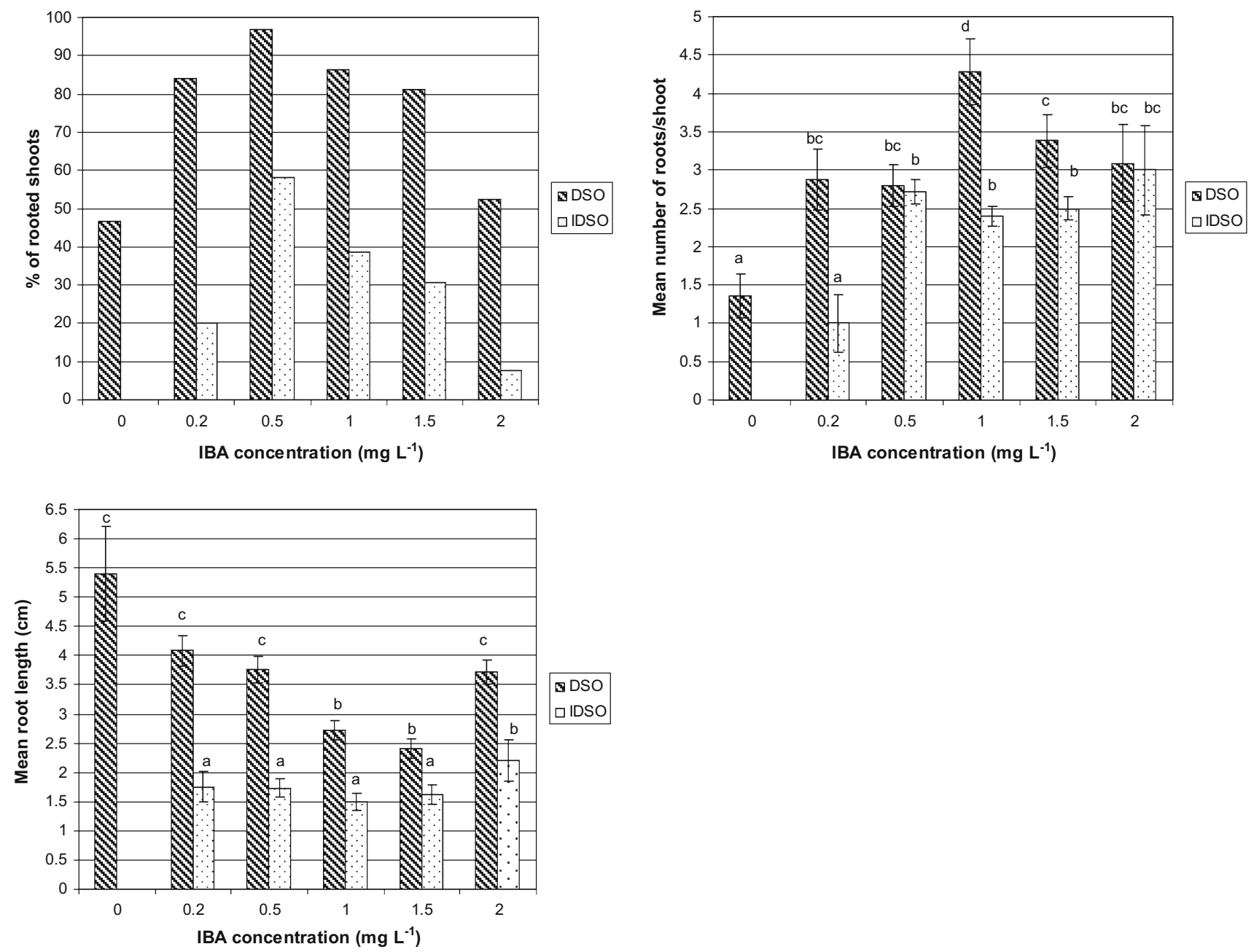

Fig. 1 Rooting of $R$. carthamoides shoots on $1 / 2$ MS medium without or supplemented with IBA. The shoots were obtained through direct organogenesis (DSO) and through indirect organogenesis (IDSO). For

mean \pm standard error from three independent experiments; means marked by the same letter are not significantly different from each other at a $5 \%$ level according to the Kruskal-Wallis test and multiple rooting the shoots were cultured for 5 weeks. Results are

Table 3 Comparison of morphological features of $R$. carthamoides plants derived in vitro through direct organogenesis (DSO-plants) and indirect organogenesis (IDSOplants) and in vivo from seeds (SP-plants)

\begin{tabular}{lllr}
\hline Measuring parameters & DSO-plants & IDSO-plants & \multicolumn{1}{c}{ SP-plants } \\
\hline Plant fresh weight $(\mathrm{g})$ & $19.7 \pm 0.48^{\mathrm{b}}$ & $13.7 \pm 0.22^{\mathrm{a}}$ & $21.1 \pm 0.47^{\mathrm{b}}$ \\
Mean plant length (cm) & $9.95 \pm 0.22^{\mathrm{b}}$ & $5.14 \pm 0.19^{\mathrm{a}}$ & $10.76 \pm 0.19^{\mathrm{b}}$ \\
Maximum root length (cm) & $24.4 \pm 0.51^{\mathrm{b}}$ & $12.3 \pm 0.11^{\mathrm{a}}$ & $25.1 \pm 0.53^{\mathrm{b}}$ \\
Number of leaves/plant & $11.2 \pm 0.59^{\mathrm{b}}$ & $6.70 \pm 0.40^{\mathrm{a}}$ & $13.70 \pm 0.49^{\mathrm{b}}$ \\
Length of leaf lamina (cm) & $6.98 \pm 0.26^{\mathrm{b}}$ & $3.44 \pm 0.18^{\mathrm{a}}$ & $7.6 \pm 0.15^{\mathrm{b}}$ \\
Width of leaf lamina (cm) & $2.31 \pm 0.06^{\mathrm{b}}$ & $1.55 \pm 0.07^{\mathrm{a}}$ & $2.51 \pm 0.04^{\mathrm{b}}$ \\
Length of leaf petiole (cm) & $2.96 \pm 0.09^{\mathrm{b}}$ & $1.7 \pm 0.06^{\mathrm{a}}$ & $3.15 \pm 0.06^{\mathrm{b}}$ \\
\hline
\end{tabular}

Plants grown in soil, in greenhouse for 3 months

Values represent mean \pm SE. Values within a rows followed by the same letter are not significantly different from each other at a $5 \%$ level according to the Kruskal-Wallis test and multiple comparisons of average ranks
$100 \mu \mathrm{M}$ dNTP (Blirt, Poland), $1.5 \mu \mathrm{L}$ of RAPD primer, $0.75 \mu \mathrm{L}$ of TaqNova DNA polymerase (Blirt, Poland) and MilliQ water to make up the volume. RAPD amplification was performed with random decamer primers obtained from Blirt (Poland). Nine RAPD primers were tested for PCR amplification. The PCR was performed at an initial 
denaturation at $95{ }^{\circ} \mathrm{C}$ for 5 min followed by 40 cycles of 1 min denaturation at $95{ }^{\circ} \mathrm{C}, 45 \mathrm{~s}$ annealing at $37{ }^{\circ} \mathrm{C}$ (and next depending on the primer, Table 4) and 2 min extension at $72{ }^{\circ} \mathrm{C}$ with a final extension of $72{ }^{\circ} \mathrm{C}$ for $7 \mathrm{~min}$ using a thermal cycler (BioRad, UK).

\section{ISSR analysis}

In case of ISSR primers, the optimal annealing temperature was found to vary according to the base composition of the primers. Eight ISSR primers (UBC primer) (Blitr, Poland) were used in the study. Amplification was carried out in $25 \mu \mathrm{L}$ reaction volume containing $2.5 \mu \mathrm{g}$ genomic DNA $(2 \mu \mathrm{L})$ as template, $1.5 \mu \mathrm{L} \mathrm{MgCl}_{2}, 0.75 \mu \mathrm{L}$ of $100 \mu \mathrm{M}$ dNTP (Blirt, Poland), $3.5 \mu \mathrm{L}$ of $10 \times$ PCR buffer (Taq buffer B devoid of $\mathrm{MgCl}_{2}$ ), $2 \mu \mathrm{L}$ of ISSR primers (10 pM), $0.75 \mu \mathrm{L}$ of TaqNova DNA polymerase (Blirt, Poland) and MilliQ water to make up the volume. PCR amplifications were performed with initial denaturation at $95{ }^{\circ} \mathrm{C}$ for $5 \mathrm{~min}$ followed by 35 cycles of $30 \mathrm{~s}$ denaturation at $94{ }^{\circ} \mathrm{C}, 1 \mathrm{~min}$ at the annealing temperature (and next depending on the primer, Table 5), 2 min extension at $72{ }^{\circ} \mathrm{C}$ with a final extension of $72{ }^{\circ} \mathrm{C}$ for $10 \mathrm{~min}$ using a thermal cycler (BioRad, UK).

The amplification RAPD-PCR and ISSR-PCR products were separated on $1.5 \%$ agarose (Bioline, UK) gel through electrophoresis using $100 \mathrm{bp}$ and $3 \mathrm{~kb}$ ladder (Fermentas, Lithuania) as the band size standard and stained with ethidium bromide and photographed using a DNR BioImaging System MiniBIS Pro (Israel). The results are presented in Tables 4, 5 and Fig. 2.

\section{Data analysis}

Two independent amplifications were performed with all the selected ISSR and RAPD primers (Tables 4, 5), and only clear and reproducible bands in the size range of $100 \mathrm{bp}-2.5 \mathrm{~kb}$ were scored. The bands were transformed into a binary character matrix for each plant material: "1" for the presence and " 0 " for the absence of a DNA band. A similarity matrix and dendrogram were constructed using the NTSYSpc 2.11X (Exeter software, Setauket, N.Y.) software package (Rohlf 2000). Genetic similarities between samples were measured by the Jaccard's similarity coefficient (Jaccard 1908). Similarity coefficients were used to construct the dendrogram using the UPGMA and SHAN routine in the NTSYS program. The results are presented in Figs. 3, 4.

\section{Flow cytometry for genome size}

Plant materials were prepared as previously described by Thiem and Śliwińska (2003). As materials were used organogenic root-callus (which was used for induction of shoot organogenesis; RC-line callus) and young, fresh leaves of $R$. carthamoides plants regenerated through direct organogenesis (DSO-plants), plants regenerated through indirect organogenesis from root-derived callus (IDSO-plants), plants obtained through clonal propagation (CP-plants), and mother plant (MP). Leaves of the mother plant were used as a control. Chicken (Gallus domesticus L.) erythrocytes (2C DNA content $=2.33 \mathrm{pg}$ ) (Hiddemann et al. 1984; Larsen et al. 1984; Ronot et al. 1986) were used as an internal standard for genome size for cell cycle estimation BD DNA QC Particles. Samples were prepared using nuclei isolation buffer $\left(0.1 \mathrm{M}\right.$ Tris, $2.5 \mathrm{mM} \mathrm{MgCl}_{2} \cdot 6 \mathrm{H}_{2} \mathrm{O}, 85 \mathrm{mM} \mathrm{NaCl}$, $0.1 \%$ Triton X-100; pH 7.0) supplemented with $1 \%$ PVP10 (Thiem and Śliwińska 2003). The plant tissues blade in plastic Petri dish with $1 \mathrm{~mL}$ nucleus-isolation buffer. The suspension was filtered through nylon filter with $50 \mu \mathrm{m}$ mesh

Table 4 Total number and size range of amplified fragments and number of polymorphic fragments generated by nine random primers in in vitro regenerated plants, callus and mother plant of $R$. carthamoides by RAPD analysis

\begin{tabular}{lllllcc}
\hline $\begin{array}{l}\text { Serial } \\
\text { no }\end{array}$ & Primer & Sequence $\left(5^{\prime}-3^{\prime}\right)$ & $\begin{array}{l}\text { Annealing } \\
\text { temperature }\left({ }^{\circ} \mathrm{C}\right)\end{array}$ & $\begin{array}{l}\text { Number of amplified } \\
\text { fragments }\end{array}$ & $\begin{array}{l}\text { Number of polymorphic } \\
\text { fragments }\end{array}$ & $\begin{array}{l}\text { Approximate fragment size } \\
\text { range }(\mathrm{bp})\end{array}$ \\
\hline 1 & OPA 1 & CAGGCCCTTC & 32 & 11 & 3 & $200-1500$ \\
2 & OPA 2 & AGCCAGGCAA & 35 & 8 & 2 & $300-1000$ \\
3 & OPA 3 & GGGTAACGCC & 34 & 7 & 2 & $200-1200$ \\
4 & OPA 4 & ATTCGGGTCG & 34 & 9 & 0 & $100-1500$ \\
5 & OPA 8 & GTGACGTAGG & 32 & 6 & 2 & $300-1200$ \\
6 & OPA 9 & GGGTAACGCC & 34 & 14 & 2 & $100-2000$ \\
7 & OPA 10 & GTGATCGCAG & 34 & 10 & 3 & $300-2500$ \\
8 & OPA 13 & CAGCACCCAC & 35 & 5 & 0 & $100-1000$ \\
9 & OPA 17 & CAGCAACGAA & 33 & 7 & 3 & $300-2000$ \\
Total & & & 77 & 19 & \\
\hline
\end{tabular}


Table 5 Total number and size range of amplified fragments and number of polymorphic fragments generated by eight random primers in in vitro regenerated plants, callus and mother plant of $R$. carthamoides by ISSR analysis

\begin{tabular}{|c|c|c|c|c|c|c|}
\hline $\begin{array}{l}\text { Serial } \\
\text { no. }\end{array}$ & Primer & $\begin{array}{l}\text { Sequence } \\
\left(5^{\prime}-3^{\prime}\right)\end{array}$ & $\begin{array}{l}\text { Annealing } \\
\text { temperature }\left({ }^{\circ} \mathrm{C}\right)\end{array}$ & $\begin{array}{l}\text { Number of amplified } \\
\text { fragments }\end{array}$ & $\begin{array}{l}\text { Number of polymorphic } \\
\text { fragments }\end{array}$ & $\begin{array}{l}\text { Approximate fragment } \\
\text { size range (bp) }\end{array}$ \\
\hline 1 & UBC 807 & $\begin{array}{l}\text { AGAGAGAGA } \\
\text { GAGAGAGT }\end{array}$ & 53 & 12 & 3 & $100-1000$ \\
\hline 2 & UBC 811 & $\begin{array}{l}\text { GAGAGAGAG } \\
\text { AGAGAGAA }\end{array}$ & 54 & 10 & 3 & $200-1500$ \\
\hline 3 & UBC 812 & $\begin{array}{l}\text { GAGAGAGAG } \\
\text { AGAGAGAC }\end{array}$ & 55 & 8 & 3 & $200-1200$ \\
\hline 4 & UBC 813 & $\begin{array}{l}\text { СТСТСТСТС } \\
\text { ТСТСТСТT }\end{array}$ & 54 & 8 & 1 & $200-1500$ \\
\hline 5 & UBC 830 & $\begin{array}{l}\text { TGTGTGTGT } \\
\text { GTGTGTGG }\end{array}$ & 52 & 6 & 2 & $100-1500$ \\
\hline 6 & UBC 834 & $\begin{array}{l}\text { AGAGAGAGA } \\
\text { GAGAGAGCT }\end{array}$ & 50 & 7 & 4 & $100-2000$ \\
\hline 7 & UBC 835 & $\begin{array}{l}\text { AGAGAGAGA } \\
\text { GAGAGAGTC }\end{array}$ & 54 & 5 & 0 & $200-1200$ \\
\hline 8 & UBC 836 & $\begin{array}{l}\text { AGAGAGAGA } \\
\text { GAGAGAGCA }\end{array}$ & 55 & 9 & 3 & $300-2500$ \\
\hline Total & & & & 65 & 23 & \\
\hline
\end{tabular}

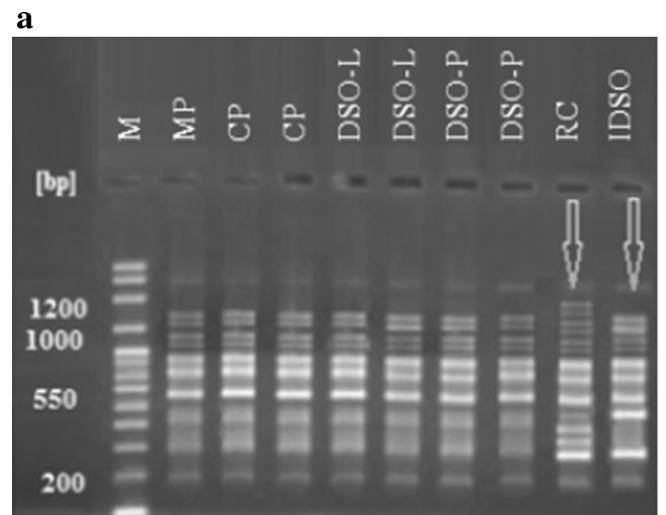

Fig. 2 Gel electrophoresis of a RAPD fragments obtained with primer OPA1 and b ISSR fragments obtained with primer UBC812. Lane $M$ DNA marker 100-3000 bp DNA ladder; lane MP DNA of $R$. carthamoides mother plant (control); lane CP plants obtained from

diameter. Samples were incubated in PBS with $75 \mu \mathrm{M}$ propidium iodide and ribonuclease A (50 Kunitz unit $/ \mathrm{mL}$ ) for $30 \mathrm{~min}\left(37{ }^{\circ} \mathrm{C}\right.$ in the dark) (Larsen et al. 1984; Ronot et al. 1986). Stainewere chopped with a sharp razord specimens were analyzed using LSR II flow cytometer (Becton-Dickinson Biologicals, USA) in channel for PE (excitation blue laser $488 \mathrm{~nm}$, emission PE channel 575/26). For each sample 5000 events were obtained. Total nuclear DNA content was calculated using linear relationship between the ratio of the $2 \mathrm{C}$ peak positions of Rhaponticum/chicken erythrocytes on a histogram of fluorescence intensities. Initial histogram analysis were performed using BD FACS DIVA software ver. 6.2, further inquiries were done using FlowJo software.

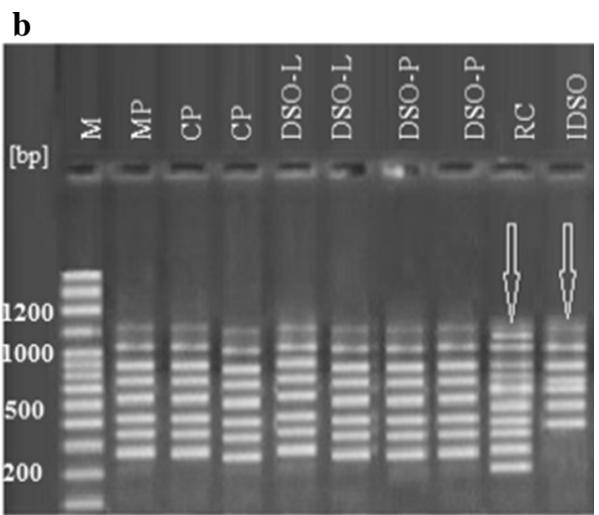

clonal propagation (control); lane DSO-L and lane DSO-P plants regenerated by direct shoot organogenesis from leaf lamina and petiole, respectively; lane $R C$ root-derived callus; lane IDSO plants regenerated by indirect shoot organogenesis

\section{Quantification of chlorogenic acid and 20- hydroxyecdysone}

\section{Extraction procedure}

The leaves and roots of DSO- and IDSO-plants, as well as seed-derived plants (SP-plants) of $R$. carthamoides were lyophilized and pulverized. All plants were grown for 3 months in pots, in the greenhouse. First, $200 \mathrm{mg}$ of plant material was extracted with $n$-hexane. After filtration, the $n$-hexane extract was discarded. The defatted sample was sonicated for 15 min with $80 \%$ (v/v) aqueous methanol $(15 \mathrm{~mL})$ at $35^{\circ} \mathrm{C}$ using an ultrasonic bath, 


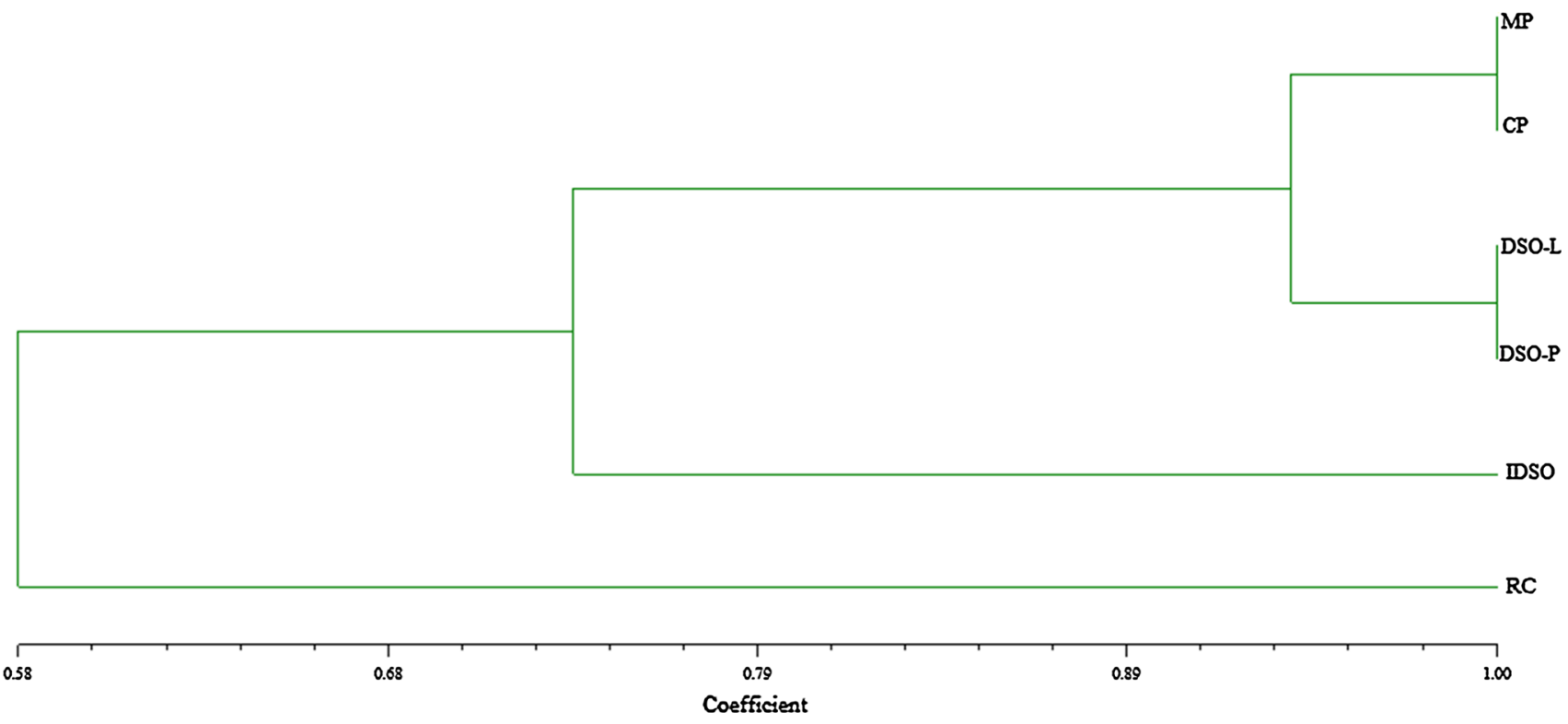

Fig. 3 Dendrogram illustrating coefficient similarities among in in vitro regenerated plants, callus line and mother plant of $R$. carthamoides by UPGMA cluster analysis (NTSYS) of the RAPD profiles derived from nine selected primers using Jaccard's similarity coefficient. $M P$ mother plant (field-grown plant), $C P$ plants obtained from axillary buds, $D S O-L$ and $D S O-P$ plants regenerated by direct shoot organogenesis from leaf lamina and petiole, respectively, IDSO plants regenerated by indirect shoot organogenesis, $R C$ root-derived callus

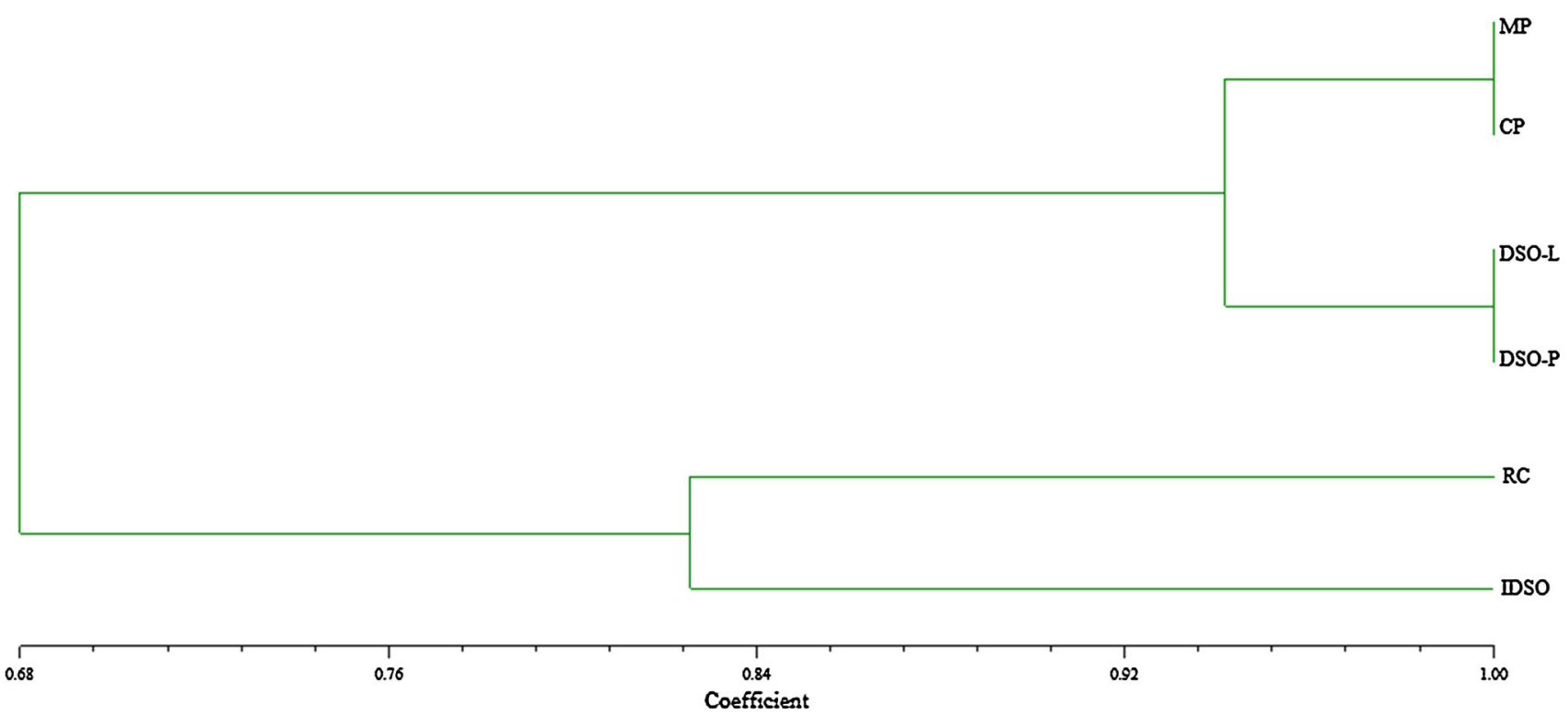

Fig. 4 Dendrogram illustrating coefficient similarities among in in vitro regenerated plants, callus line and mother plant of $R$. carthamoides by UPGMA cluster analysis (NTSYS) of the ISSR

and then twice with $5 \mathrm{~mL}$ of the same solvent for $15 \mathrm{~min}$. The combined extracts were diluted with methanol to $25 \mathrm{~mL}$, filtered through a PTFE syringe filter (25 mm, $0.2 \mu \mathrm{m}$, AlChem, Czech Republic) and the filtrate was directly injected into the UHPLC-DAD system for quantitative determination of chlorogenic acid and 20-hydroxyecdysone. profiles derived from eight selected primers using Jaccard's similarity coefficient. Symbols are given in Fig. 3

\section{UHPLC-DAD analysis}

Chromatographic analysis was performed using an Agilent Technologies 1290 Infinity UHPLC apparatus equipped with the diode array detector (DAD), the binary solvent delivery pump with included a vacuum degasser, autosampler and thermostated column compartment. 
During the UHPLC analyses, the samples of extracts were maintained in the autosampler at $15^{\circ} \mathrm{C}$ in the dark. The separations of the samples were performed on the Zorbax Eclipse Plus C18 column $(100 \times 3 \mathrm{~mm}$ id; $1.8 \mu \mathrm{m}$ Agilent Technologies, Cat. no 928975-302) at $30{ }^{\circ} \mathrm{C}$. The mobile phase consisted of $0.5 \%$ phosphoric acid in acetonitrile (v/v) (solvent A) and $0.5 \%$ phosphoric acid (v/v) in water (solvent B). A gradient program was applied as follows: 0-1 $\min 1 \% \mathrm{~A} ; 1-1.4 \min 1-5 \% \mathrm{~A} ; 1.4-3.5 \min 5 \% \mathrm{~A}$; 3.5-4 min 5-19\% A; 4-6.5 min $19 \%$ A; 6.5-6.9 min 19-30\% A; 6.9-7.5 min $30-35 \% \quad \mathrm{~A} ; \quad 7.5-9.5 \mathrm{~min}$ 35-95\% A; 9.5-11 min $95 \%$ A. The column was equilibrated with $1 \%$ of the solvent $\mathrm{A}$ for 4 min between injections. The flow rate was $0.6 \mathrm{~mL} \mathrm{~min}{ }^{-1}$. The injection volume was $5 \mu \mathrm{L}$. The detection wavelength was set at $245 \mathrm{~nm}$ with a $4 \mathrm{~nm}$ bandwidth. Chlorogenic acid and 20-hydroxyecdysone (20-HE) were identified by comparing their UV spectra and retention times of their peaks (Rt 5.55 and $7.94 \mathrm{~min}$, respectively) (Fig. 5) with those of the reference compounds. Authentic standards of chlorogenic acid and 20-HE were purchased from Sigma-Aldrich (Germany/USA). Chlorogenic acid and 20-HE contents were estimated by the interpolation of the peaks area with calibration curves constructed for the standard compounds. The content of the chlorogenic acid and 20-HE were estimated as $\mathrm{mg}$ per gram of dry weight $\left(\mathrm{mg} \mathrm{g}^{-1} \mathrm{DW}\right)$ of leaves or roots. The results are presented in Table 7 .

\section{Results and disscusion}

\section{Indirect shoot regeneration}

Organogenesis from $R$. carthamoides seedling explants (hypocotyl, cotyledons, roots) was induced indirectly via an intervening callus phase. The shoot regeneration ability of $R$. carthamoides in terms of the percentage of explants producing organogenic calluses and number of buds/shoots per responding callus was tested by culturing segments of hypocotyl, cotyledons and roots on MS basal medium containing a combination of BA $\left(0.2\right.$ or $\left.0.5 \mathrm{mg} \mathrm{L}^{-1}\right)$ with one of three auxins: 2,4-D, NAA or IBA $(0.2$ or $0.5 \mathrm{mg} \mathrm{L}^{-1}$; Table 1). The choice of media for induction of shoot-regenerating callus was based on our own preliminary experiments and a review of earlier studies ( $\mathrm{Li}$ et al. 2013; Zand et al. 2014). Zand et al. (2014) report the highest shoot regeneration (89\%) from R. carthamoides leaf explants cultured on MS medium supplemented with 2,4-D $\left(0.25 \mathrm{mg} \mathrm{L}^{-1}\right)$ and BA $\left(1.5 \mathrm{mg} \mathrm{L}^{-1}\right)$. However, in the current study, only induction of non-organogenic callus or callus forming roots was observed in the presence of 2,4D $\left(0.2\right.$ or $\left.0.5 \mathrm{mg} \mathrm{L}^{-1}\right)$ with BA $\left(0.2\right.$ or $\left.0.5 \mathrm{mg} \mathrm{L}^{-1}\right) . R$ carthamoides shoot regeneration was possible when calluses were cultured in the presence of NAA or IBA as auxin and BA as cytokinin (Table 1). Following 5 weeks of culture on the media, most seedling explants formed compact, green or yellow-green regenerative callus with buds and shoots. The calluses were transferred into fresh medium of the same composition as that used for callus induction to allow the growth of callus biomass and further development of shoots. Of the two auxins (NAA and IBA), NAA was found to be more effective for shoot regeneration than IBA. The maximum number of buds/shoots (almost 4 per callus) and the highest percentage cultures producing buds/shoots (92\%) were achieved when cotyledon-derived calluses were cultured on MS medium containing NAA (0.5 mg L $\left.{ }^{-1}\right)$ and BA (0.2 $\left.\mathrm{mg} \mathrm{L}^{-1}\right)$. Root-derived calluses cultured on the same medium composition showed a similar ability to bud/shoot regeneration and more than 3 buds/ shoots per callus were formed at the frequency of organogenesis of $83 \%$. Significant reductions in the number of buds/shoots (about 2 per callus) was obtained when hypocotyl explants were used for callus initiation (Table 1). It was also observed that with each subculture, the ability of $R$. carthamoides seedling-derived calluses to shoot differentiation declined. Only calluses initiated from roots and cultured for 1 year on MS medium containing NAA and BA maintained competence to form shoots (Fig. 6a) and the shoots excised from the calluses were used for the rooting stage.

\section{Direct shoot organogenesis}

Direct shoot organogenesis was achieved by using leaves from in vitro shoot culture of $R$. carthamoides, as initial explants. Lamina and petiole explants were incubated on six variations of MS media. The media contained BA alone and in combination with NAA or IBA as shown in Table 2. Combination of 2,4-D $\left(0.2\right.$ or $\left.0.5 \mathrm{mg} \mathrm{L}^{-1}\right)$ and BA $\left(0.2\right.$ or $\left.0.5 \mathrm{mg} \mathrm{L}^{-1}\right)$ was also tested but responses induced under these conditions were inefficient, therefore the variants were not shown. Shoot organogenesis did not occur from leaf explants cultured in the absence of plant growth regulators. Formation of adventitious buds and shoots from the cut ends or along the whole surface of petiole explants, and the mid-vein or whole surface of lamina explants (Fig. 6e), was observed after 5 weeks of culture with high frequency $(83-100 \%)$ and a mean number of 3-4.5 buds/shoots per explant, both in response to BA alone and in combination with NAA or IBA. The maximum number of buds/shoots (approximately 4.5 per responsive explant) was achieved on MS medium supplemented with $0.2 \mathrm{mg} \mathrm{L}^{-1} \mathrm{BA}$ and $0.5 \mathrm{mg} \mathrm{L}^{-1} \mathrm{NAA}$. On this medium high bud/shoot regeneration frequency (93.5-100\%) was also achieved. The lowest organogenesis frequency $(83-86 \%)$ and number of buds/shoots 
Fig. 5 UHPLC chromatogram at $245 \mathrm{~nm}$ of methanolic extract from leaves of $R$. carthamoides seed-derived plants. 1 chlorogenic acid; 2 20-hydroxyecdysone

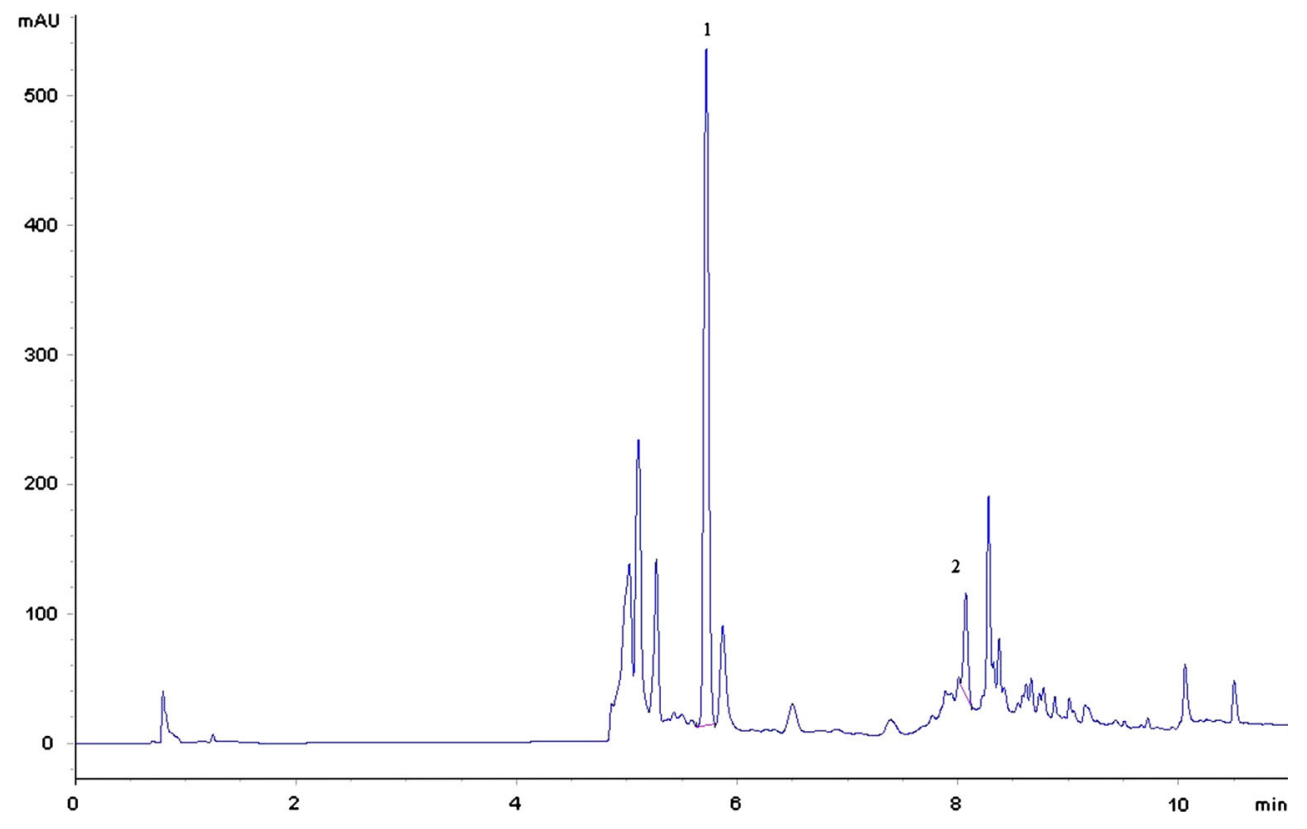

to $1.0 \mathrm{mg} \mathrm{L}^{-1}$ decreased the rooting percentage to $86 \%$ but increased the mean number of roots per shoot (4.3 vs. 2.8; Fig. 1). The positive effect of IBA on root induction has also been reported for other species in Asteraceae family such as Cichorium intybus (Velayutham et al. 2006) and C. pumilum (Al Khateeb et al. 2012). Application of IBA induces adventitious roots, due to an increase in the biosynthesis of IAA (Woodward and Bartel 2005).

It was noted that the type of regeneration of $R$. carthamoides shoots (indirectly from root-derived callus and directly from leaf explants) affects the time of root initiation and the rooting efficiency in terms of percentage of shoots forming roots, root branching and root length. On shoots obtained from leaf explants through direct organogenesis the roots started to initiate after 7 days and within 5 weeks of culture on optimal medium ( $1 / 2$ MS supplemented with $0.5 \mathrm{mg} \mathrm{L}^{-1}$ IBA) $97 \%$ of the shoots formed an average 2.8 roots with an average length of $3.7 \mathrm{~cm}$. The plants developed an adventitious roots system with numerous lateral branching and with high adsorption capacity (Fig. 6f). In the case of shoots derived from callus, root initiation commenced after 14 days and at the end of culture period ( 5 weeks) a maximum $58 \%$ of the shoots formed an average 2.7 roots with an average length of $1.7 \mathrm{~cm}$. The root system of these plants lacked lateral roots (Fig. 6b). As shown in Fig. 1, the presence of IBA was necessary for rooting of shoots derived from callus.

The rooted shoots were transplanted into small pots containing soil, sand, peat and perlite for further growth in the greenhouse. Three months after transfer to ex vitro conditions all, the DSO-plants survived (plants regenerated directly from leaf explants), while the survival rate for 

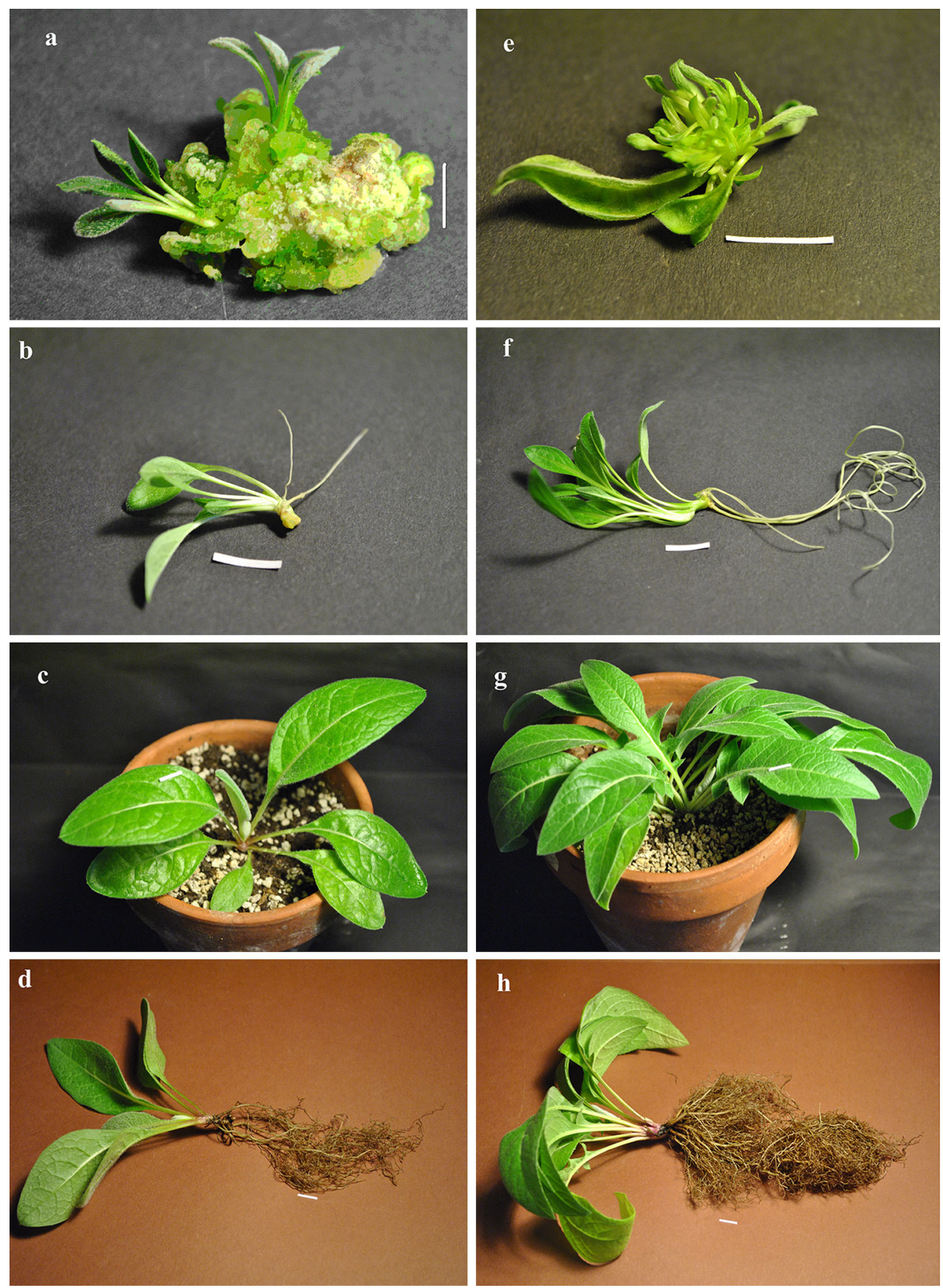

Fig. 6 Regeneration of $R$. carthamoides through indirect organogenesis (a-d) and direct organogenesis (e-h). Adventitious shoot formation from root-derived callus (a) and from leaf lamina (e).

IDSO-plants (plants regenerated from root-derived callus) reached only $44 \%$. The lack of lateral roots in IDSO-plants (Fig. 6b) adversely impacts their adsorptive capacity, contributing to a lower survival rate under ex vitro conditions. In many plant species, high mortality has been observed upon the transfer of rooted shoots to soil as the cultured plants have weak root system (Mathur et al. 2008; Chandra et al. 2010).

Shoot rooted on $1 / 2 \mathrm{MS}$ medium supplemented with $0.5 \mathrm{mg} \mathrm{L}^{-1}$ IBA after 5 weeks of culture $(\mathbf{b}, \mathbf{f})$. Plants after 3 months of growth in pots $(\mathbf{c}, \mathbf{g})$ and after removing from pots $(\mathbf{d}, \mathbf{h})$. Bars $1 \mathrm{~cm}$

\section{Morphological characterization of plants grown in greenhouse}

Observation of growth in greenhouse revealed that the morphology of regenerated plants varied and was dependent on whether they are derived through direct or indirect organogenesis (Table 3; Figs. 6, 7). After 3 months, DSOplants were taller and their total fresh weight was almost 
twice higher than that in IDSO-plants (Table 3). The former had more leaves and longer, thicker and more branched roots (Fig. 6g-h). Significant differences exist also between both plants in respect to shape of leaves (Fig. 7). This phenomenon may be caused by somaclonal variation as a result of callus culture. No significant differences in any measuring growth parameters were observed between $R$. carthamoides plants developed through direct organogenesis and those propagated from seeds, which were the same age and grew under identical conditions as in vitro developed plants (Table 3).

\section{Analysis of genetic stability by RAPD and ISSR and flow cytometry}

To determine the genetic stability of in vitro regenerated plants of $R$. carthamoides, we compared the genetic fidelity of the plants derived through direct (from lamina-DSO-Lplants and petiole-DSO-P-plants) and indirect organogenesis (IDSO-plants) using RAPD and ISSR markers. In addition, the RC callus line (callus derived from a root explant which was used for the induction of shoot organogenesis) was also included in the analysis, while the mother plant (MP) and plants regenerated in vitro from axillary buds (CP-plants) were used as control materials. The plants propagated from meristematic tissues exhibited the lowest tendency for genetic variation (Mallón et al. 2010; Bhatia et al. 2011). The initial RAPD and ISSR analyses of all 10 randomly-selected plants of each group
(DSO-, IDSO- and CP-plants) for every tested primers showed that no genetic variation was present within them.

In RAPD-PCR analysis, the nine primers were selected for DNA amplification (Table 4). The molecular size of the RAPD fragments ranged from 100 to $2500 \mathrm{bp}$. The number of amplified fragments varied from 5 (OPA 13) to 14 (OPA 9) (Table 4). The 9 primers, produced a total of 77 bands with an average of 8.5 bands per primer. Among these 9 amplified primers, 7 generated polymorphic bands. Out of the 77 scorable bands, 19 were polymorphic with an average number of polymorphic bands per primer as 2.1 . The levels of polymorphism were varied according to primers. The highest number (3) of polymorphic bands was obtained by primer OPA 1 , OPA 10 and OPA 17 and the lowest (0) by primer OPA 4 and OPA 13 (Table 4). The similarity matrix calculated from the RAPD profiles was subsequently subjected by UPGMA cluster analysis using NTSYS software in order to evaluate the genetic fidelity (Fig. 3).

The Jaccard's similarity coefficient of dendrogram among MP-, CP-plants (used as the control material) and DSO-L-, DSO-P-, IDSO-plants and RC line callus ranged from 0.588 to 0.941 (Fig. 3). DSO-L- and DSO-P-plants showed maximum closeness between together, with a similarity coefficient of 1.000 and a similarity coefficient of 0.941 to MP- and CP-plants (Fig. 3). IDSO-plants were closely related to MP-, CP-, DSO-P- and DSO-L-plants but the similarity values were low and ranged from 0.706 to 0.765 (Fig. 3).
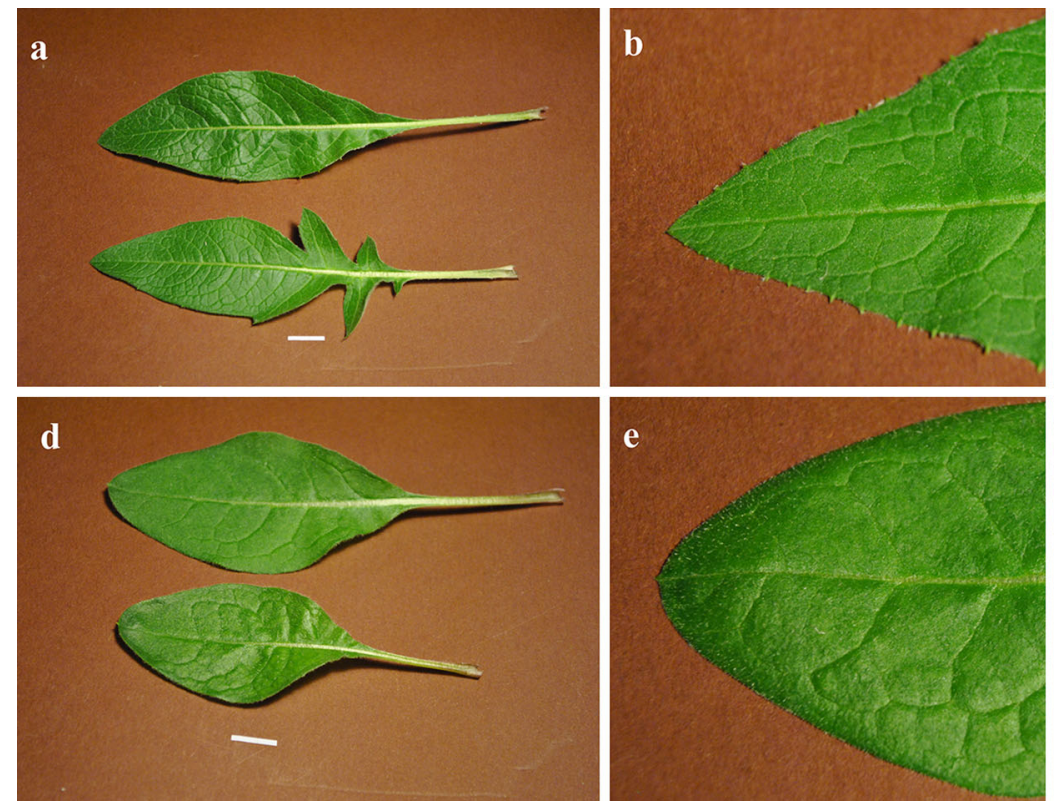
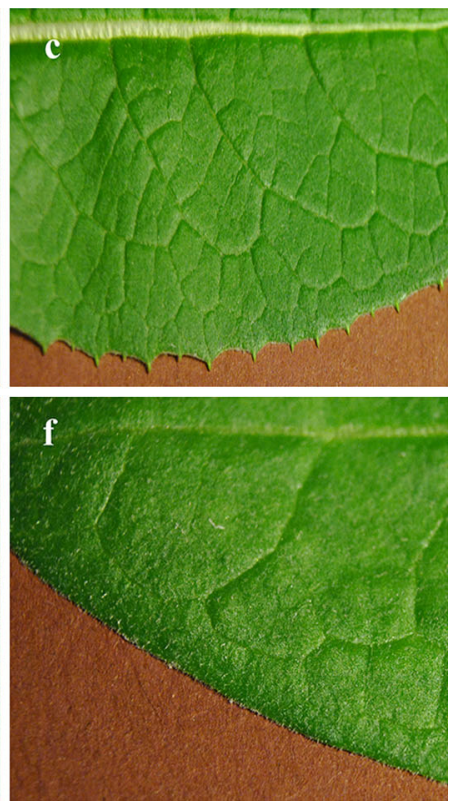

Fig. 7 Alteration in the leaf morphology of $R$. carthamoides plants regenerated through direct $(\mathbf{a}-\mathbf{c})$ and indirect $(\mathbf{d}-\mathbf{f})$ shoot organogenesis. Bars $1 \mathrm{~cm} \mathrm{(e)}$ 
During ISSR-PCR analysis, the molecular size of amplified products ranged from 100 to $2500 \mathrm{bp}$ (Table 5). The highest number of bands (12) was obtained in case of primer UBC 807, whereas the lowest number of bands (5) was recorded for the primer UBC 835 (Table 5). The eight selected ISSR primers generated a total of 65 bands, with an average of 8.1 bands per primer. Among these amplified primers, only one generated monomorphic bands (UBC 835; Table 5). Of the 65 fragments scored from ISSR primers, 42 were monomorphic and 23 were polymorphic with an average number of 2.9 polymorphic bands per primer (Table 5). The primer UBC 834 gave the highest number of polymorphic bands (4) while UBC 835 gave the lowest (0; Table 5).

The Jaccard's similarity coefficient calculated on the basis of the ISSR data revealed different levels of genetic variation than the RAPD-PCR analysis. The analysis revealed that the genetic identity of DSO-L-, DSO-P- and IDSO-plants and the callus with the MP- and CP-plants (control materials), ranged from 0.647 to 0.947 (Fig. 4). Maximum genetic similarity to the MP- and CP-plants was observed for DSO-L- and DSO-P-plants, similarly as to the coefficient calculated of the RAPD data (0.947) (Figs. 3, 4). As shown in the dendrogram (Fig. 4), the IDSO-plants were clustered to RC callus (0.824).

In order to test the genetic variability of the plants regenerated through direct (DSO-plants) and indirect organogenesis (IDSO-plants), clonal propagation (CPplants) and RC callus line, the flow cytometry was also used. Flow cytometry is widely used to establish the nuclear DNA content, genome size or ploidy level in in vitro cultures (Ochatt et al. 2011; Makowczyńska et al. 2008; Slazak et al. 2015; Peng et al. 2015). The genome size of diploid mother plant of $R$. carthamoides was $2.27 \mathrm{pg} / 2 \mathrm{C}$ (Table 6). To our knowledge, this is the first report on genome size in this species. The $2 \mathrm{C}$ DNA content in CP-, DSO-L-, DSO-P-plants was similar (2.33-2.38 pg; no statistical difference) to the mother plant (Table 6). The plants regenerated through indirect organogenesis and $\mathrm{RC}$ callus line showed higher nuclear DNA content (2.47 and $3.19 \mathrm{pg} / 2 \mathrm{C}$, respectively) than the mother plant (a significant difference; $p<0.05)$.

In this study, the genetic identity of DSO-plants of $R$. carthamoides to the mother plant and axillary buds-derived plants was high and ranged from 0.941 to 0.947 . Flow cytometry confirmed similar ploidy level in the mother plant and DSO- and axillary buds-derived plants (the nuclear DNA content was 2.33-2.38 pg/2C). Our results suggested that the direct plant regeneration from the explant tissues might ensure the low genetic variation.

Somaclonal variation has been frequently reported in in vitro regenerated plants (Larkin and Scowcroft 1981). The occurrence of variation during in vitro propagation depends upon the source of explants and the pathway of plant regeneration (Goto et al. 1998). Somaclonal variation is quite often associated with indirect regeneration involving an intervening callus stage (Shen et al. 2007; Yuan et al. 2009). Similar results were observed in this study for $R$. carthamoides plants regenerated through indirect shoot organogenesis from root-derived callus. The plants showed a low similarity coefficient to the mother plant and axillary bud-derived plants, which ranged from 0.647 to 0.706 . Also, the nuclear DNA content in IDSOplants was higher $(2.47 \mathrm{pg} / 2 \mathrm{C})$ than in the mother plant ( $2.27 \mathrm{pg} / 2 \mathrm{C}$ ) (a significant difference; $p<0.05$ ). Since single seedling was used to initiate shoot regenerative callus, the genetic polymorphism of IDSO-plants of $R$. carthamoides can not be due to the genetic variability of seeds but rather somaclonal variation induced by in vitro propagation. The major reason for increase in somaclonal variation upon indirect regeneration may be increase in genetic heterogeneity of callus cells. The similarity coefficient between IDSO-plants and callus was found to be relatively lower in RAPD analysis (0.588) than those assessed in ISSR analysis (similarity coefficient was 0.824).

The in vitro tissue culture condition (particularly callus induction) induces physiological stress, which may be characterized by disruption of normal developmental controls, and the mechanism for the occurrence of somaclonal variation can be largely explained in the context of preadapted cellular responses to stress (Cassells and Curry 2001). The responses may include activation of an otherwise cryptic mutator system like transposition, and/or malfunction of a normally functional anti-mutational system such as the mismatch repair (Guo et al. 2006). Somaclonal variation can be manifested as cytological abnormalities, various kinds of aberrations at the nucleotide sequence level (substitution, deletion, insertion), and

Table 6 Nuclear DNA content in callus and regenerated in vitro plants of $R$. carthamoides

\begin{tabular}{ll}
\hline Plant material & Nuclear DNA content $(\mathrm{pg} / 2 \mathrm{C} \pm \mathrm{SE})$ \\
\hline MP & $2.27 \pm 0.05^{\mathrm{a}}$ \\
$\mathrm{CP}$ & $2.33 \pm 0.01^{\mathrm{a}}$ \\
DSO & $2.38 \pm 0.01^{\mathrm{ab}}$ \\
IDSO & $2.47 \pm 0.03^{\mathrm{b}}$ \\
RC & $3.19 \pm 0.01^{\mathrm{c}}$
\end{tabular}

Each value represent the mean \pm standard error (SE) of nine independent samples. Values with the same letter are not significantly different from each other at a $5 \%$ level according to the KruskalWallis test and multiple comparisons of average ranks

MP, mother plant; CP, plants obtained from clonal propagation; DSO, plants regenerated by direct shoot organogenesis; IDSO, plants regenerated by indirect shoot organogenesis; RC, root-derived callus 
gene activation and silencing (Kaeppler et al. 2000; Guo et al. 2006).

Although, somaclonal variation is undesirable in micropropagation but it can be an important source of new variability as for example new cultivar development. The overall results presented that direct organogenesis is good method for generation of genetically stable clones of $R$. carthamoides identical to mother plant.

\section{Quantification of chlorogenic acid and 20- hydroxyecdysone}

In order to evaluate the effect of the type of regeneration pathway on secondary metabolite production, UHPLCDAD method was used to quantify the chlorogenic acid and 20-hydroxyecdysone (20-HE) in methanolic extracts of leaves and roots of 3-month-old DSO- and IDSO-plants of $R$. carthamoides and compared with those in leaves and roots of corresponding seed-derived plants (SP). A typical chromatogram of methanolic extracts is shown in Fig. 5 where peak 1 is related to chlorogenic acid and peak 2 to 20-HE. Both compounds are typical of $R$. carthamoides species (Kokoska and Janovska 2009; Biskup et al. 2013). Chlorogenic acid accounts for most of the content of caffeic acid derivatives in $R$. carthamoides and we used the compound as a marker of caffeic acid derivatives. As shown in Table 7, the DSO- and IDSO-plants demonstrated significantly different levels of chlorogenic acid, as did plant leaves and roots. The chlorogenic acid content in DSO-plant leaves was found to be 13-times $\left(12.2 \mathrm{mg} \mathrm{g}^{-1}\right.$ DW) greater than in leaves of IDSO-plants $\left(0.9 \mathrm{mg} \mathrm{g}^{-1}\right.$ DW). In contrast, the average content of chlorogenic acid in roots of DSO-plants was $2.5 \mathrm{mg} \mathrm{g}^{-1} \mathrm{DW}: 1.5$ times lower than in the roots of IDSO-plants $\left(3.9 \mathrm{mg} \mathrm{g}^{-1} \mathrm{DW}\right)$.

The other class of bioactive compounds in $R$. carthamoides are phytoecdysteroids. Among them, 20-hydroxyecdysone is dominant (Kokoska and Janovska 2009). The results presented in Table 7 show that the average content of 20-HE in leaves and roots of IDSO-plants were found to be 3- and 1.5-times higher than those in leaves and roots of DSO-plants (7.4 $\mathrm{mg} \mathrm{g}^{-1} \mathrm{DW}$ and $3.04 \mathrm{mg} \mathrm{g}^{-1} \mathrm{DW}$ vs. 2.5 and $2.1 \mathrm{mg} \mathrm{g}^{-1} \mathrm{DW}$, respectively). Chavan et al. (2014) also note the presence of quantitative differences between Ceropegia santapaui plants regenerated through indirect and direct organogenesis, with the former exhibiting increased levels of total phenolics and flavonoids. So far, the biosynthetic differences have not been well clarified. Chavan et al. (2014) suggest that these might be due to the exogenous supply of the plant growth regulators during in vitro multiplication.

In comparison to SP-plants, DSO-plants exhibited similar levels of both chlorogenic acid and 20-HE. A significant difference $(p<0.05)$ was observed only in terms of
Table 7 Quantitative analysis of chlorogenic acid and 20-hydroxyecdysone in plants of $R$. carthamoides regenerated in vitro and in the seed-derived plants, growing in greenhouse for 3 months

\begin{tabular}{llcl}
\hline Plant origin & Plant organ & \multicolumn{2}{c}{ Content $\left(\mathrm{mg} \mathrm{g}^{-1} \mathrm{DW}\right) \pm \mathrm{SE}$} \\
\cline { 3 - 4 } & & Chlorogenic acid & \multicolumn{2}{l}{ 20-HE } \\
\hline DSO & Leaves & $12.23 \pm 0.13^{\mathrm{d}}$ & $2.46 \pm 0.07^{\mathrm{b}}$ \\
& Roots & $2.49 \pm 0.03^{\mathrm{b}}$ & $2.12 \pm 0.04^{\mathrm{b}}$ \\
\multirow{2}{*}{ IDSO } & Leaves & $0.94 \pm 0.03^{\mathrm{a}}$ & $7.38 \pm 0.05^{\mathrm{c}}$ \\
& Roots & $3.9 \pm 0.17^{\mathrm{c}}$ & $3.04 \pm 0.07^{\mathrm{a}}$ \\
SP & Leaves & $11.58 \pm 0.37^{\mathrm{d}}$ & $2.38 \pm 0.11^{\mathrm{b}}$ \\
& Roots & $3.31 \pm 0.19^{\mathrm{c}}$ & $2.02 \pm 0.06^{\mathrm{b}}$ \\
\hline
\end{tabular}

Each value represent the mean \pm standard error (SE) of three independent samples. Each sample was repeated three times $(n=9)$. Values within a column followed by the same letter are not significantly different from each other at a $5 \%$ level according to the Kruskal-Wallis test and multiple comparisons of average ranks

DSO, plants regenerated by direct shoot organogenesis from leaf explants; IDSO, plants regenerated from root-derived callus; SP, seed-derived plants

the chlorogenic acid content in roots of these plants, which was $33 \%$ higher in SP-plant roots. The leaves and roots of the IDSO-plants contained significantly higher amounts of 20-HE than the analogous parts of SP-plants (Table 7). In respect to chlorogenic acid, leaves of IDSO-plants accumulated only one tenth of the compound level found in the leaves of the SP-plants, while the roots of both plants contained similar levels of the caffeic acid derivative (Table 7).

This is the first report comparing the chlorogenic acid and 20-HE contents in in vitro- and in vivo-derived plants of $R$. carthamoides. The levels of chlorogenic acid in methanolic extracts from the leaves of mature $R$. carthamoides plants were found to be $0.63 \mathrm{mg} \mathrm{g}^{-1} \mathrm{DW}$ in those growing in Russia and $2.0 \mathrm{mg} \mathrm{g}^{-1} \mathrm{DW}$ in those growing in Poland (Biskup et al. 2013). Timofeev et al. (2006) report that the level of 20-HE HE varied from 0.15 to $0.55 \%$ on the basis of dry weight in 8- to 11-year-old $R$. carthamoides plants, depending on organ and stage of plant development.

In summary, $R$. carthamoides plants regenerated trough direct organogenesis (from leaf explants) and indirect organogenesis via callus tissue (from seedling explants) were obtained in this work. The pathway of regeneration affected the rooting of in vitro derived shoots, the survival of plantlets under ex vitro conditions, their morphology and the modified metabolic activity of in vitro regenerated plants. It was observed that while the leaves of plants obtained from direct organogenesis were a better source of chlorogenic acid than the leaves of regenerants obtained from callus culture, the later exhibited a superior potential for accumulation of 20-HE. Phenotypic changes and overproduction of $20-\mathrm{HE}$ in plants obtained through 
indirect organogenesis could be related to somaclonal variation. The RAPD and ISSR analyses indicated the heterogeneity of regenerants derived from callus culture versus $R$. carthamoides mother plant and plants regenerated directly from explant tissue.

Conflict of interest The authors declare no conflict of interest.

Open Access This article is distributed under the terms of the Creative Commons Attribution 4.0 International License (http://crea tivecommons.org/licenses/by/4.0/), which permits unrestricted use, distribution, and reproduction in any medium, provided you give appropriate credit to the original author(s) and the source, provide a link to the Creative Commons license, and indicate if changes were made.

\section{References}

Al Khateeb W, Hussein E, Qouta L, Alu'datt M, Al-Shara B, Abuzaiton A (2012) In vitro propagation and characterization of phenolic content along with antioxidant and antimicrobial activities of Cichorium pumilum Jacq. Plant Cell Tissue Organ Cult 110:103-110. doi:10.1007/s11240-012-0134-9

Bhatia R, Singh KP, Sharma TR, Jhang T (2011) Evaluation of the genetic fidelity of in vitro-propagated gerbera (Gerbera jamesonii Bolus) using DNA-based markers. Plant Cell Tissue Organ Cult 104:131-135. doi:10.1007/s11240-010-9806-5

Biskup E, Lojkowska E (2009) Evaluation of biological activities of Rhaponticum carthamoides extracts. J Med Plant Res 31:1092-1098

Biskup E, Szynklarz B, Golebiowski M, Borsuk K, Stepnowski P, Lojkowska E (2013) Composition and biological activity of Rhaponticum carthamoides extracts obtained from plants collected in Poland and Russia. J Med Plant Res 7:687-695. doi:10. 5897/JMPR012.1061

Cassells AC, Curry RF (2001) Oxidative stress and physiological, epigenetic and genetic variability in plant tissue culture: implications for micropropagators and genetic engineers. Plant Cell Tissue Organ Cult 64:145-157. doi:10.1023/A:1010692104861

Chandra S, Bandopadhyay R, Kumar V, Chandra R (2010) Acclimatization of tissue cultured plantlets: from laboratory to land. Biotechnol Lett 32:1199-1205. doi:10.1007/s10529-010-0290-0

Chavan JJ, Gaikwad NB, Umdale SD, Kshirsagar PR, Bhat KV, Yadav SR (2014) Efficiency of direct and indirect shoot organogenesis, molecular profiling, secondary metabolite production and antioxidant activity of micropropagated Ceropegia santapaui. Plant Growth Regul 72:1-15. doi:10.1007/s10725-013-9830-7

Clifford MN (1999) Chlorogenic acids and other cinnamates-nature, occurrence and dietary burden. J Sci Food Agric 79:362-372. doi:10.1002/(SICI)1097-0010(19990301)79:3<362:AIDJSFA 256>3.0.CO;2-D

Duškova J, Dušek J (1995) Leuzea carthamoides DC in vitro. Herba Polonica 41:165-169

Goto S, Thakur RC, Ishii K (1998) Determination of genetic stability in long-term micropropagated shoots of Pinus thunbergii Parl. Using RAPD markers. Plant Cell Rep 18:193-197. doi:10.1007/ s002990050555

Guo WL, Gong L, Ding ZF, Li YD, Li FX, Zhao SP, Liu B (2006) Genomic instability in phenotypically normal regenerants of medicinal plant Codonopsis lanceolata Benth. et Hook. f., as revealed by ISSR and RAPD markers. Plant Cell Rep 25:896-906. doi:10.1007/s00299-006-0131-8
Hiddemann W, Schaumann J, Andreeff M, Barlogie B, Herman ChJ, Leif RC, Mayall BH, Murphy RF, Sandberg AA (1984) Convention on nomenclature for DNA cytometry. Cytometry 5:445-446

Jaccard P (1908) Nouvelles recherches surla distribution florale. Bull Soc Vaud Sci Nat 44:223-270. doi:10.5169/seals-268384

Kaeppler SM, Kaeppler HF, Rhee Y (2000) Epigenetic aspects of somaclonal variation in plants. Plant Mol Biol 43:179-188. doi:10.1023/A:1006423110134

Kokoska L, Janovska D (2009) Chemistry and pharmacology of Rhaponticum carthamoides: a review. Phytochemistry 70:842-855. doi:10.1016/j.phytochem.2009.04.008

Kokoska L, Polesny Z, Rada V, Nepovim A, Vanek T (2002) Screening of some Siberian medicinal plants for antimicrobial activity. J Ethnopharmacol 82:51-53

Larkin P, Scowcroft W (1981) Somaclonal variation-a novel source of variability from cell cultures for plant improvement. Theor Appl Genet 60:197-214. doi:10.1007/BF02342540

Larsen JK, Munch-Petersen B, Christiansen J, Brgensen KJ (1984) Flow cytometry for discrimination of mitotic cells: resolution of $\mathrm{M}$, as well as G1, S and G2 phase nucei with mitharamycin, propidium iodide, and ethidium bromide after fixation with formaldehyde. Cytometry 7:54-63

Li Q, Deng M, Zhang J, Zhao W, Song Y, Li Q, Huang Q (2013) Shoot organogenesis and plant regeneration from leaf explants of Lysionotus serratus D. Don. Sci World J:1-7. doi: 10.1155/2013/ 280384

Liu F, Huang L-L, Li Y-L, Reinhoud P, Jongsma MA, Wang C-Y (2011) Shoot organogenesis in leaf explants of Hydrangea macrophylla 'Hyd1' and assessing genetic stabiltity of regenerants using ISSR markers. Plant Tissue Organ Cult 104:111-117. doi:10.1007/s11240-010-9797-2

Makowczyńska J, Andrzejewska-Golec E, Sliwinska E (2008) Nuclear content in different plant materials of Plantago asiatica L. cultured in vitro. Plant Cell Tissue Organ Cult 94:65-71. doi:10.1007/s11240-008-9387-8

Mallón R, Rodríguez-Oubiña J, González ML (2010) In vitro propagation of the endangered plant Centaurea ultreiae: assessment of genetic stability by cytological studies, flow cytometry and RAPD analysis. Plant Cell Tissue Organ Cult 101:31-39. doi:10.1007/s11240-009-9659-y

Mathur A, Mathur AK, Verma P, Yadav S, Gupta ML, Darokar MP (2008) Biological hardening and genetic fidelity testing of micro-cloned progeny of Chlorophytum borivilianum Sant. et Fernand. Afr J Biotechnol 7:1046-1053. doi:10.5897/AJB07.760

Mohat S, Parthasarathy U, Asish GR, Babu KN (2012) Evaluation of genetic stability of micropropagated plants of three species of Garcinia using random amplified Polymorphic DNA (RAPD) and inter simple sequence repeat (ISSR) markers. Indian J Biotechnol 11:341-343

Murashige T, Skoog F (1962) A revised medium for rapid growth and bioassays with tobacco tissue cultures. Physiol Plant 15:473-497. doi:10.1111/j.1399-3054.1962.tb08052.x

Nayak SA, Kumar S, Satapathy K, Moharana A, Behera B, Barik DP, Acharya L, Mohapatra PK, Jena PK, Naik SK (2013) In vitro plant regeneration from cotyledonary nodes of Withania somnifera (L.) Dunal and assessment of clonal fidelity using RAPD and ISSR markers. Acta Physiol Plant 35:195-203. doi:10.1007/ s11738-012-1063-2

Ochatt SJ, Patat-Ochatt EM, Moessner A (2011) Ploidy level determination within the context of in vitro breeding. Plant Cell Tissue Organ Cult 104:329-341. doi:10.1007/s11240-011-9918-6

Olthof MR, Hollman PC, Katan MB (2001) Chlorogenic acid and caffeic acid are absorbed in humans. J Nutr 131:66-71 
Palla KJ, Pijut PM (2011) Regeneration of plants from Fraxinus americana hypocotyls and cotyledons. In Vitro Cell Dev Biol Plant 47:250-256. doi:10.1007/s11627-011-9360-9

Peng X, Zhang T-T, Zhang J (2015) Effect of subculture times on genetic fidelity, endogenous hormone level and pharmaceutical potential of Tetrastigma hemsleyanum callus. Plant Cell Tissue Organ Cult 122:67-77. doi:10.1007/s11240-015-0750-2

Rohlf FJ (2000) NTSYS-pc: numerical taxonomy and multivariate analysis system. Exeter Software, New York

Ronot X, Hecquet C, Larno S, Hainque B, Adolphe M (1986) $\mathrm{G}_{2}$ Arrest, binucleation and single parameter DNA flow cytometry analysis. Cytometry 7:286-290

Shen X, Chen J, Kane ME, Henny RJ (2007) Assessment of somaclonal variation in Dieffenbachia plants regenerated through indirect shoot organogenesis. Plant Cell Tissue Organ Cult 91:21-27. doi:10.1007/s11240-007-9273-9

Sláma K, Lafont R (1995) Insect hormones-ecdysteroids: their presence and actions in vertebrate. Eur J Entomol 92:355-377

Slazak B, Sliwinska E, Saługa M, Ronikier M, Bujak J, Słomka A, Göransson U, Kuta E (2015) Micropropagation of Viola uliginosa (Violaceae) for endangered species conservation and for somaclonal variation-enhanced cyclotide biosynthesis. Plant Cell Tissue Organ Cult 120:179-190. doi:10.1007/s11240-0140592-3

Thiem B, Śliwińska E (2003) Flow cytometric analysis of nuclear DNA content in cloudberry (Rubus chamaemorus L.) in vitro cultures. Plant Sci 164:129-134
Timofeev NP, Lapin AA, Zelenkov VN (2006) Quality assessment of Rhaponticum carthamoides (Willd.) Iljin as medicinal raw material by the bromic antioxidant capacity. Chem Comput Simul Butlerov Commun 8:35-40

Velayutham P, Ranjithakumari BD, Baskaran P (2006) An efficient in vitro plant regeneration system for Cichorium intybus L.-an important medicinal plant. J Agric Tech 2:287-298

Woodward AW, Bartel B (2005) Auxin: regulation, action, and interaction. Ann Bot 95:707-735

Yuan XF, Dai ZH, Wang XD, Zhao B (2009) Assessment of genetic stability in tissue-cultured products and seedlings of Saussurea involucrate by RAPD and ISSR markers. Biotechnol Lett 31:1279-1287. doi:10.1007/s10529-009-9984-6

Zand A, Babaei A, Omidbaigi R, Daneshfar E (2014) Study on callus induction and plant regeneration of Leuzea carthamoides via tissue culture system. J Med Plant Res 8:260-268. doi:10.5897/ JMPR11.610

Zhou L, Cheng Z, Chen D (2012) Simultaneous determination of six steroidal saponins and one ecdysone in Asparagus filicinus using high performance liquid chromatography coupled with evaporative light scattering detection. Acta Pharm Sin B 2:267-273. doi:10.1016/j.apsb.2012.04.003 